\title{
Determination of the Chemical Composition of Lady's Bedstraw (Galium verum L.) Herb Extract by GC-MS
}

\author{
Zaichikova SG', Bokov DO ${ }^{1,2, *}$, Kiselevskii MV ${ }^{3}$, Antsyshkina AM', Bondar AA ${ }^{1}$, Prostodusheva TV ${ }^{1}$, \\ Shchepochkina OYu' ${ }^{1}$, Gegechkori VI'
}

Zaichikova SG', Bokov DO Kiselevskii MV³ , Antsyshkina AM', Bondar AA', Prostodusheva TV', Shchepochkina OYu', Gegechkori $\mathrm{VI}^{1}$

'A.P. Nelyubin Institute of Pharmacy, Sechenov First Moscow State Medical University, 8 Trubetskaya St., bldg. 2, Moscow, 119991, RUSSIAN FEDERATION. ${ }^{2}$ Laboratory of Food Chemistry, Federal Research Center of Nutrition, Biotechnology and Food Safety, 2/14 Ustyinsky pr., Moscow, 109240, RUSSIAN FEDERATION. ${ }^{3}$ Laboratory of Cell-Mediated Immunity, Blokhin National Medical Research Center of Oncology, 24, Kashirskoye sh., Moscow, 115478, RUSSIAN FEDERATION.

\section{Correspondence}

\section{Bokov DO}

A.P. Nelyubin Institute of Pharmacy, Sechenov First Moscow State Medical University, 8 Trubetskaya St., bldg. 2, Moscow, 119991; Laboratory of Food Chemistry, Federal Research Center of Nutrition, Biotechnology and Food Safety, 2/14 Ustyinsky pr., Moscow, 109240 RUSSIAN FEDERATION.

E-mail:fmmsu@mail.ru

History

- Submission Date: 27-03-2020;

- Review completed: 14-04-2020;

- Accepted Date: 04-05-2020;

DOI : 10.5530/pj.2020.12.123

Article Available online http://www.phcogj.com/v12/i4

Copyright

(C) 2020 Phcogj.Com. This is an openaccess article distributed under the terms of the Creative Commons Attribution 4.0 International license.

\section{ABSTRACT}

Background: The research is devoted to the study of the Lady's bedstraw (Galium verum L.) herb ethanol extract composition using the method of gas chromatography with mass spectrometric detection. Materials and Methods: Air-dried G. verum L. herb was used for ethanol extract preparation. Hewlett Packard 6890, 5973A GC/MSD System equipped with an HP-5MS quartz capillary column with geometric dimensions of $30 \mathrm{~m} \times 0.25 \mathrm{~mm} \times 0.25 \mu \mathrm{m}$ was used for GC-MS analysis. Results: It was established that the Lady's bedstraw ethanol extract is rich in biologically active substances that determine its wide spectrum of pharmacological action. 15 compounds were identified by comparing with library mass spectra. Conclusions: $G$. verum $\mathrm{L}$. is a promising source of crude herbal drugs. In the future, after additional pharmacognostic studies, G. verum L. herb can be recommended for implementation in the State Pharmacopeia of the Russian Federation.

Key words: Lady's bedstraw, Galium verum L., Ethanol extract, Gas chromatography-mass spectrometry.

\section{INTRODUCTION}

The search for new sources of plant materials and the creation of herbal medicine products based on them with high therapeutic efficacy and low toxicity is currently demanded. Lady's bedstraw (Galium verum L., Figure 1.1. ${ }^{1}$ ), the Rubiaceae family, is of considerable interest for study. It has a wide range of pharmacological effects and is used only in traditional medicine. G. verum L. crude herbal drugs (CHD) have anti-inflammatory, antioxidant, antiseptic, restorative, choleretic, analgesic, diuretic, antispasmodic, estrogenic effects. Also, this plant is used in the prevention and treatment of cancer. ${ }^{2-5}$ The chemical composition of the $G$. verum $\mathrm{L}$ is very rich and diverse; it contains tannins ${ }^{6}$, triterpene compounds ${ }^{7}$, essential oil ${ }^{8}$, organic acids ${ }^{9}$, carotenoids ${ }^{10}$, flavonoids ${ }^{11,12}$, iridoid glycosides $^{13}$, anthracene derivatives ${ }^{14}$ and other biologically active compounds (BAC). Earlier, we studied the toxicity of Lady's bedstraw aqueous extract in experiments on laboratory animals. We concluded that the Lady's bedstraw liquid extract refers to IV class, known as slightly hazardous substances according to the classification of chemicals by hazard. ${ }^{15}$

As G. verum L. herb possesses a wide spectrum of biological activity (including cancer prevention and treatment) our research aimed to carry out an in-depth study of the plant's ethanol extract chemical composition by gas chromatography with mass spectrometric detection

\section{MATERIALS AND METHODS}

\section{Plant material}

G. verum L. herb was collected in July 2018 in the southwest of the Moscow region (Russia), dried in the air-shade.

\section{Sample preparation}

Sample of the raw material was ground to a particle size passing through a sieve with a hole size of 2 mm. Lady's bedstraw ethanol extract (1:10) was prepared using $70 \%$ ethanol. Then it was evaporated in a nitrogen stream at room temperature to $0.1 \mathrm{~cm}^{3}$ residual volume. The prepared sample was analyzed by gas chromatography with a mass spectrometric detector in total ion current mode.

\section{Instrumentals}

Hewlett Packard 6890, 5973A GC/MSD System equipped with an HP-5MS quartz capillary column with geometric dimensions of $30 \mathrm{~m} \times 0.25 \mathrm{~mm} \times 0.25$ $\mu \mathrm{m}$ was used. The stationary phase is $5 \%$ diphenyl-95 $\%$ dimethylpolysiloxane.

\section{Gas chromatography conditions}

The temperature program was applied as follows. Thermostat: initial $-36 \pm 1^{\circ} \mathrm{C}$, hold $36^{\circ} \mathrm{C}-1 \mathrm{~min}$, final $-260 \pm 1$, hold $260^{\circ} \mathrm{C}-5 \mathrm{~min}$, injector temperature $150^{\circ} \mathrm{C}$. Injector split ratio was $10: 1$, the temperature programming rate of the column thermostat is $5^{\circ} \mathrm{C} /$ min from 36 to $60^{\circ} \mathrm{C}$, then $15^{\circ} \mathrm{C} / \mathrm{min}$ from 60 to 260 ${ }^{\circ} \mathrm{C}$. The carrier gas (helium) flow rate is $1 \pm 0.1 \mathrm{ml} /$ min. The injected sample volume is $1 \mu \mathrm{l}$.

\section{Mass-spectrometry conditions}

Ionization voltage: $-70 \mathrm{eV}$, ion source temperature - $230{ }^{\circ} \mathrm{C}$, quadrupole temperature $-150{ }^{\circ} \mathrm{C}$, intermediate line temperature $-280{ }^{\circ} \mathrm{C}$, mass scanning range of $15-550 \mathrm{~m} / \mathrm{z}$, gas hold-up time -2.0 min.
Cite this article: Zaichikova SG, Bokov DO, Kiselevskii MV, Antsyshkina AM, Bondar AA, Prostodusheva TV, et al. Determination of the Chemical Composition of Lady's Bedstraw (Galium verum L.) Herb Extract by GC-MS. Pharmacogn J. 2020;12(4):857-63. 


\section{RESULTS AND DISCUSSION}

The result of G. verum L. herb ethanol extract qualitative analysis is presented in Table 1.

G. verum L. herb ethanol extract chromatogram is presented in Figure 2.

The mass spectra of the identified compounds (compared to library mass spectra) are shown in Figures 3-10.

The identified compounds, for the most part, are fatty acids and their esters in Lady's bedstraw herb ethanol extract. Phytol - an acyclic aliphatic organic chemical compound, refers to diterpenes, that have monounsaturated isoprene residues as a base. Phytol is part of chlorophyll, vitamin $\mathrm{E}$, vitamin $\mathrm{K}_{1}$ as a phytyl substitute.

\section{CONCLUSION}

We identified 15 compounds not previously described in the literature. Identification is based on the Lady's bedstraw herb ethanol extract mass spectrometric studies. The obtained data can be used in further study of Lady's bedstraw and the creation of new herbal medicine products and regulatory documentation on its basis.

\section{Table 1: Identified compounds in Lady's bedstraw herb ethanol extract.}

\begin{tabular}{cclcc}
\hline No & Retention time, min & \multicolumn{1}{c}{ Compound name } & Chemical formula & M. W. \\
A. W. U.
\end{tabular}
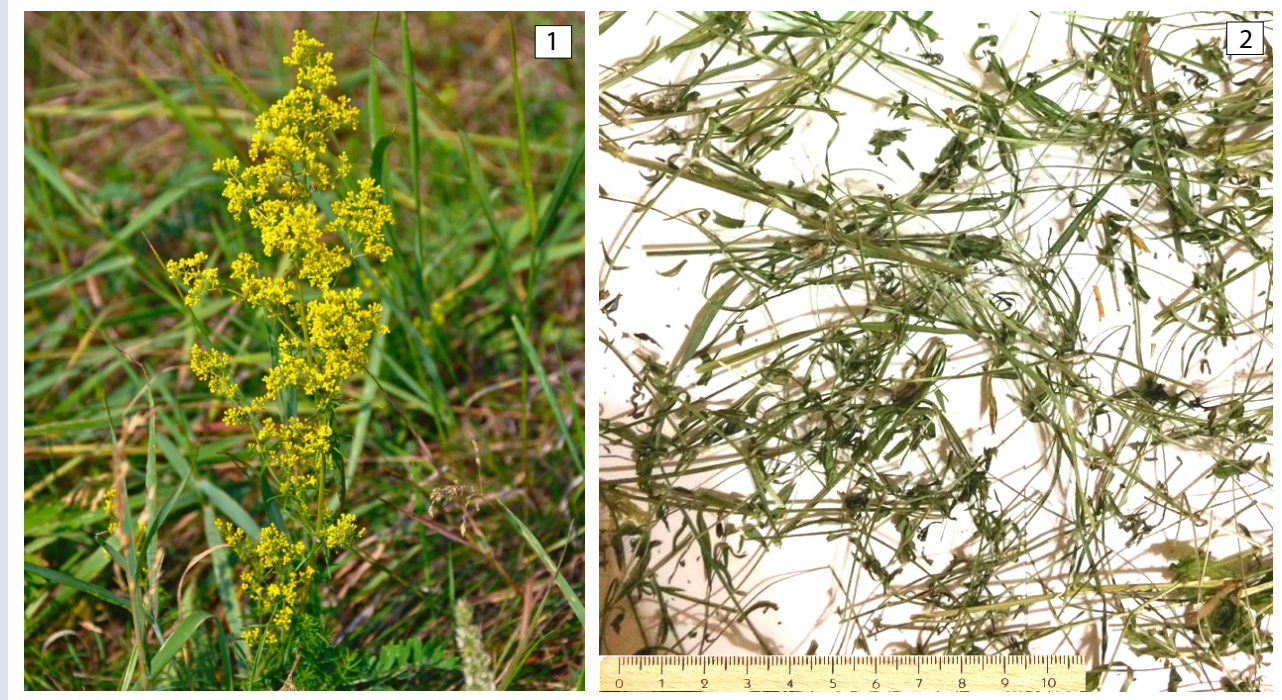

Figure 1: Lady's bedstraw (Galium verum L.): flowering plant (1), crude herbal drug (2). 


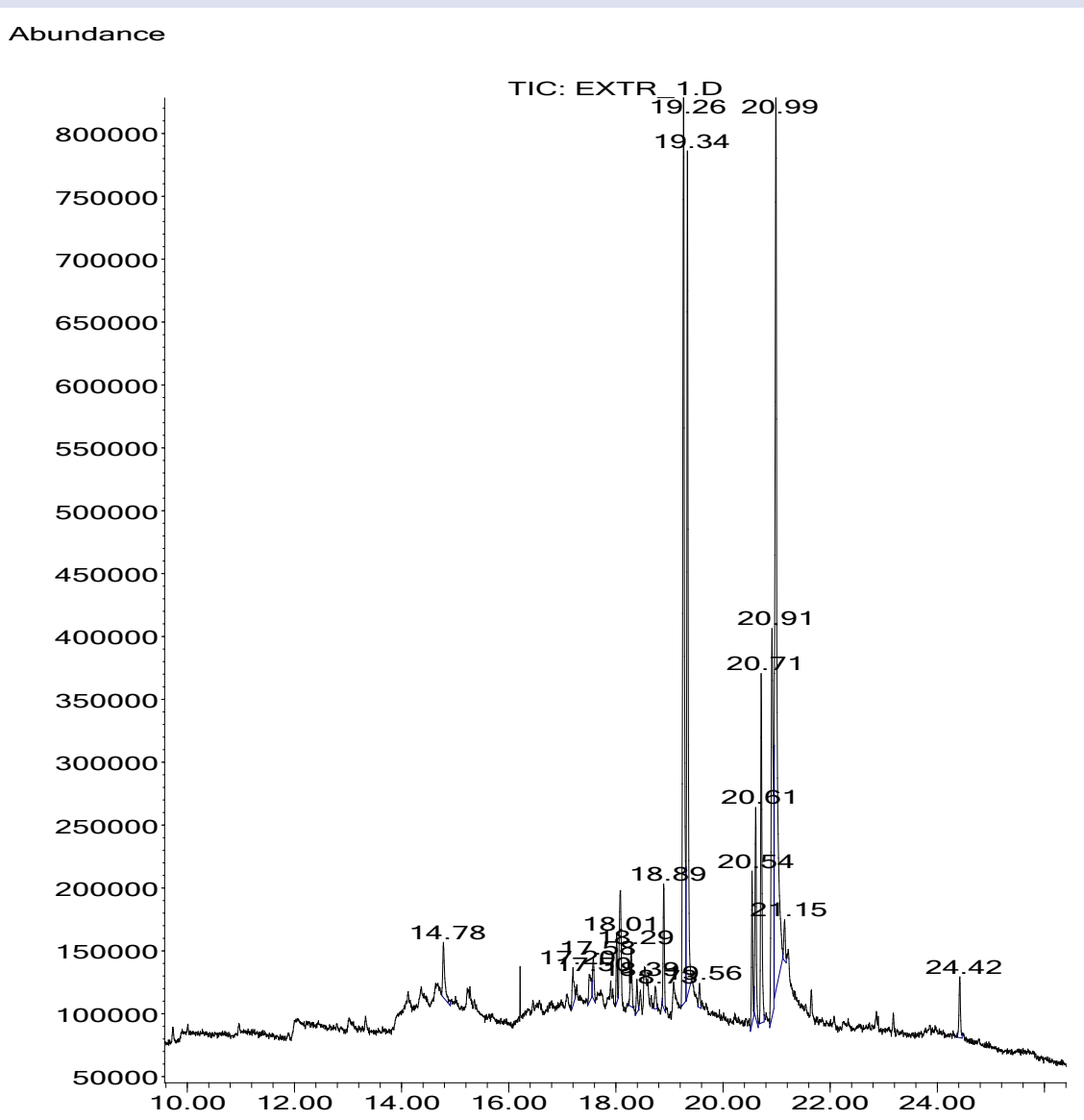

Time-->

Figure 2: Chromatogram of chemical compounds in Lady's bedstraw alcohol extract.

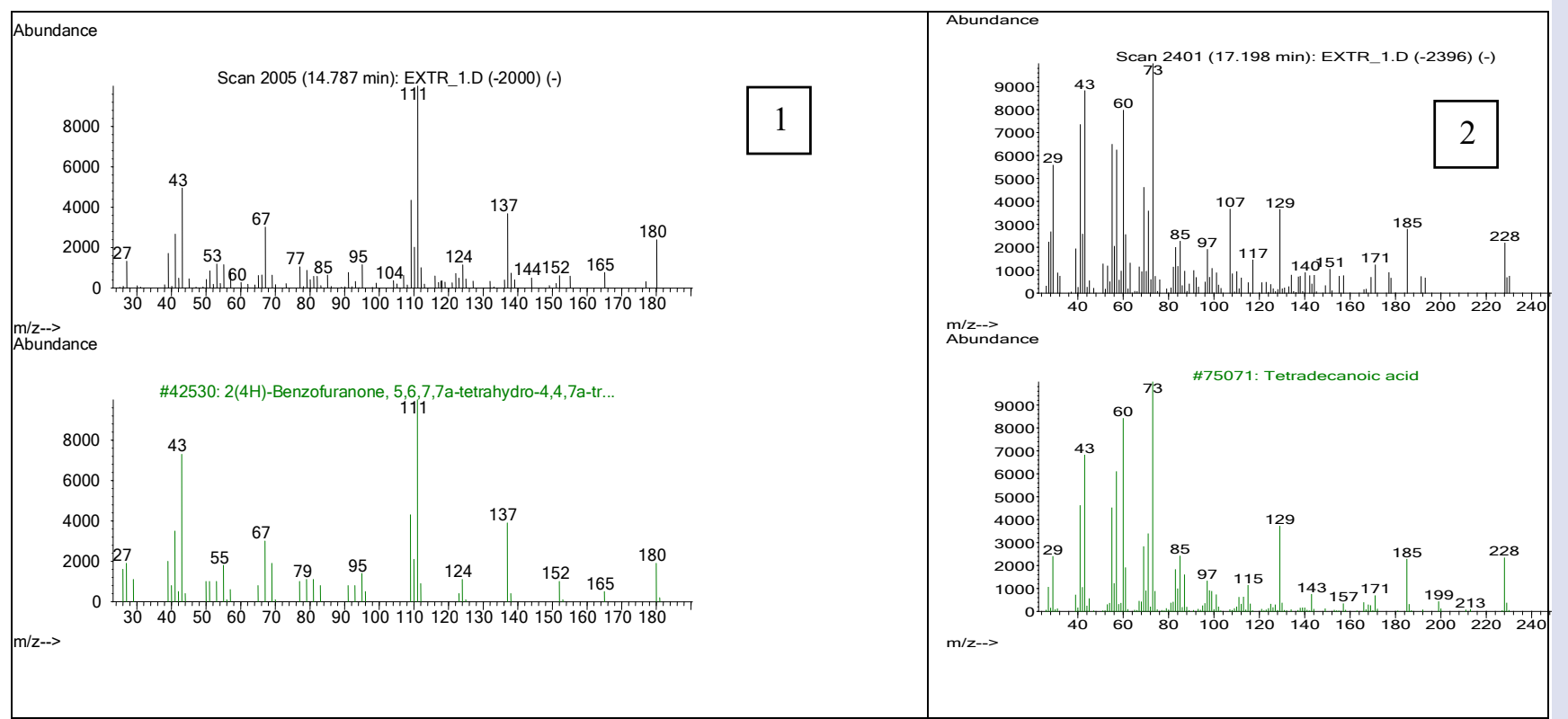

Figure 3: 5,6,7,7A-Tetrahydro-4,4,7A-trimethyl-2(4H)-benzofuranone (1), tetradecanoic acid (2) mass-spectra. 


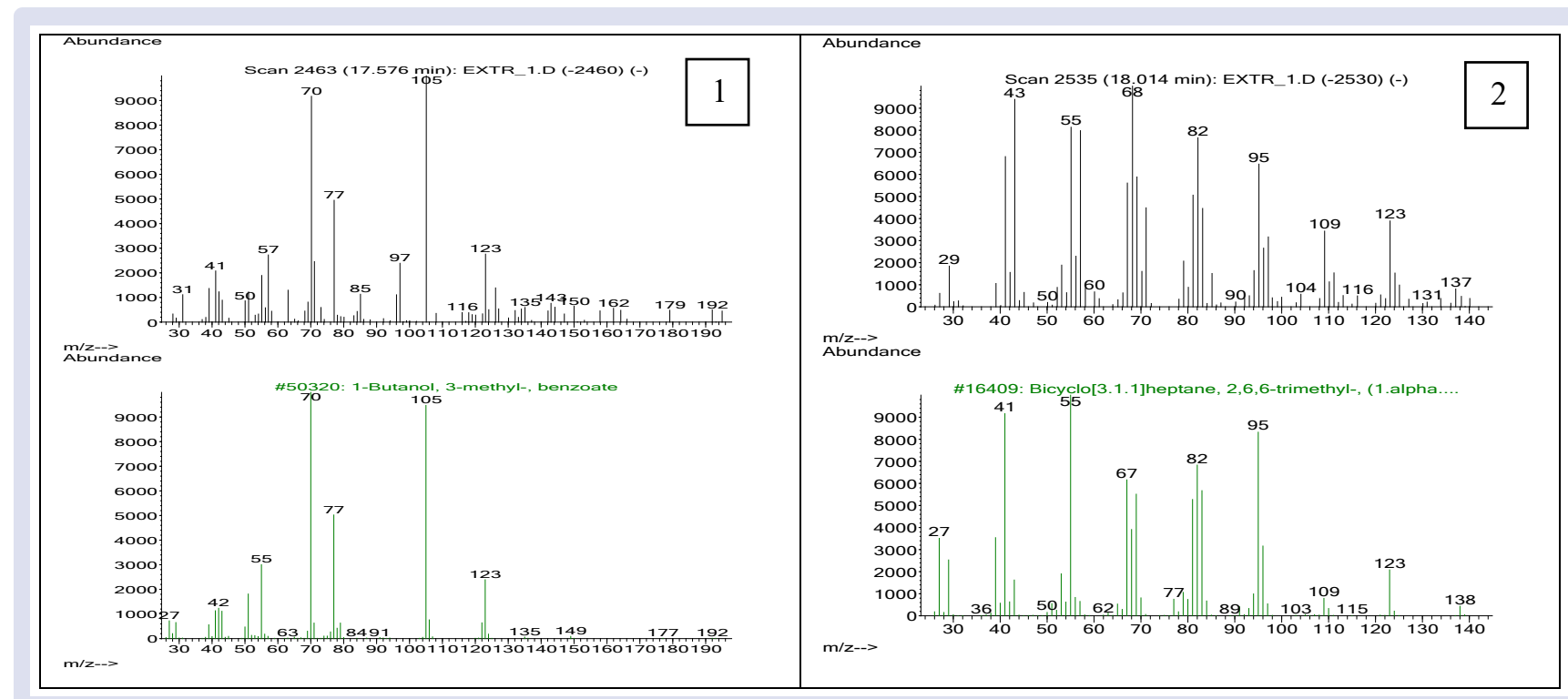

Figure 4: 3-Methyl-1-butanolbenzoate (1), bicycle[3.1.1]heptanes (2) mass-spectra.

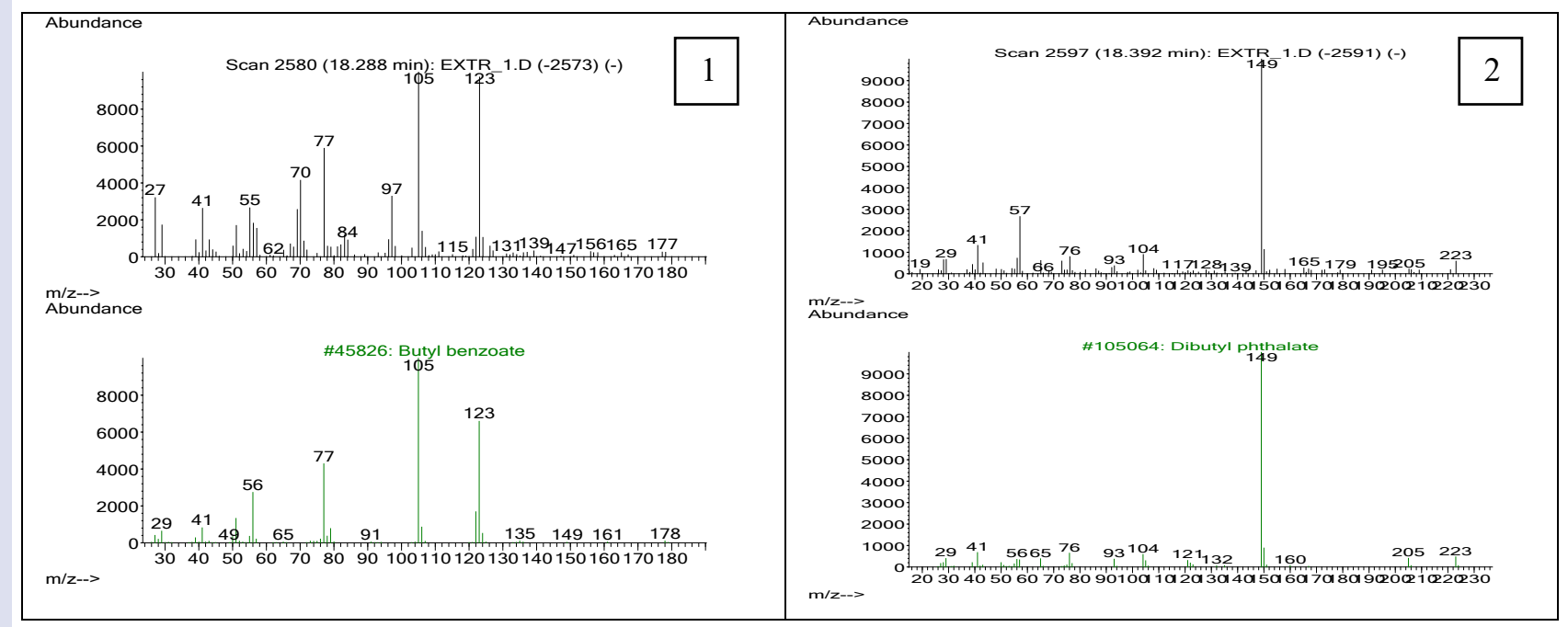

Figure 5: butylbenzoate (1), dibutyl phthalate (2) mass-spectra.

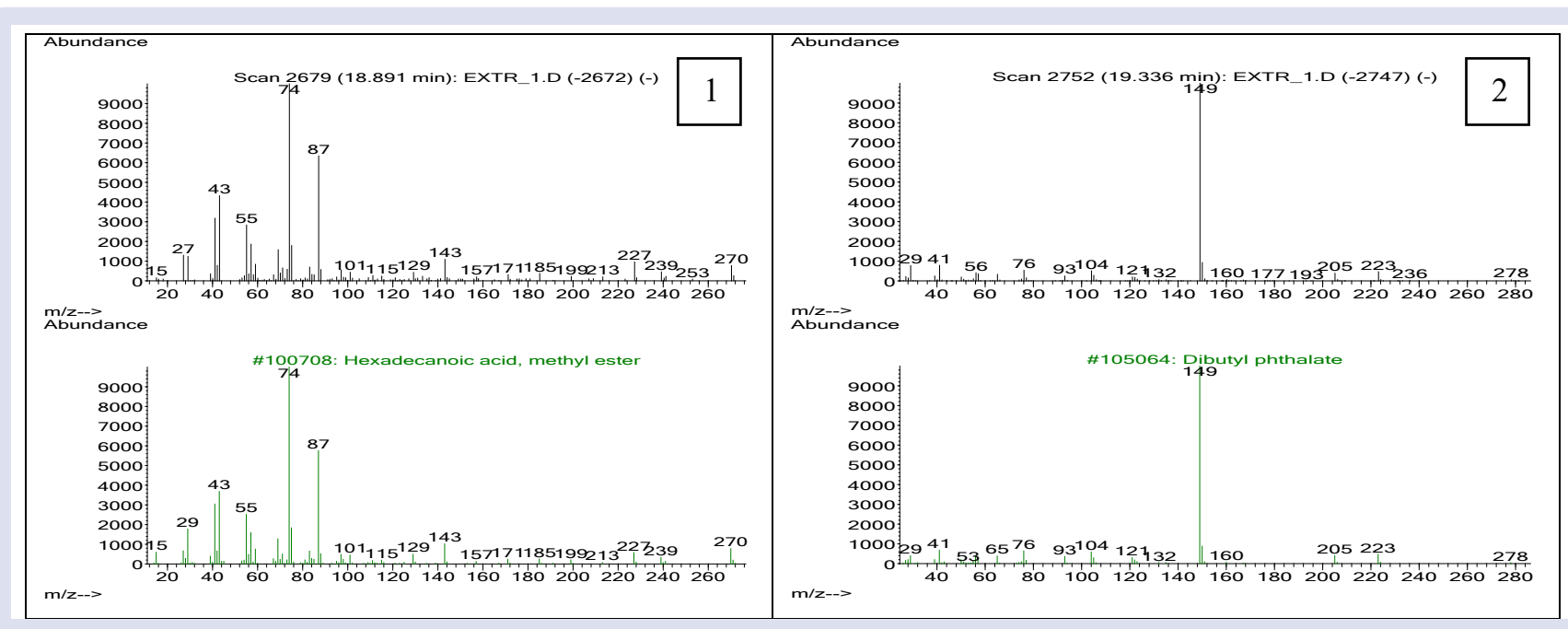

Figure 6: Hexadecanoic acid methyl ester (1), dibutyl phthalate (2) mass-spectra. 


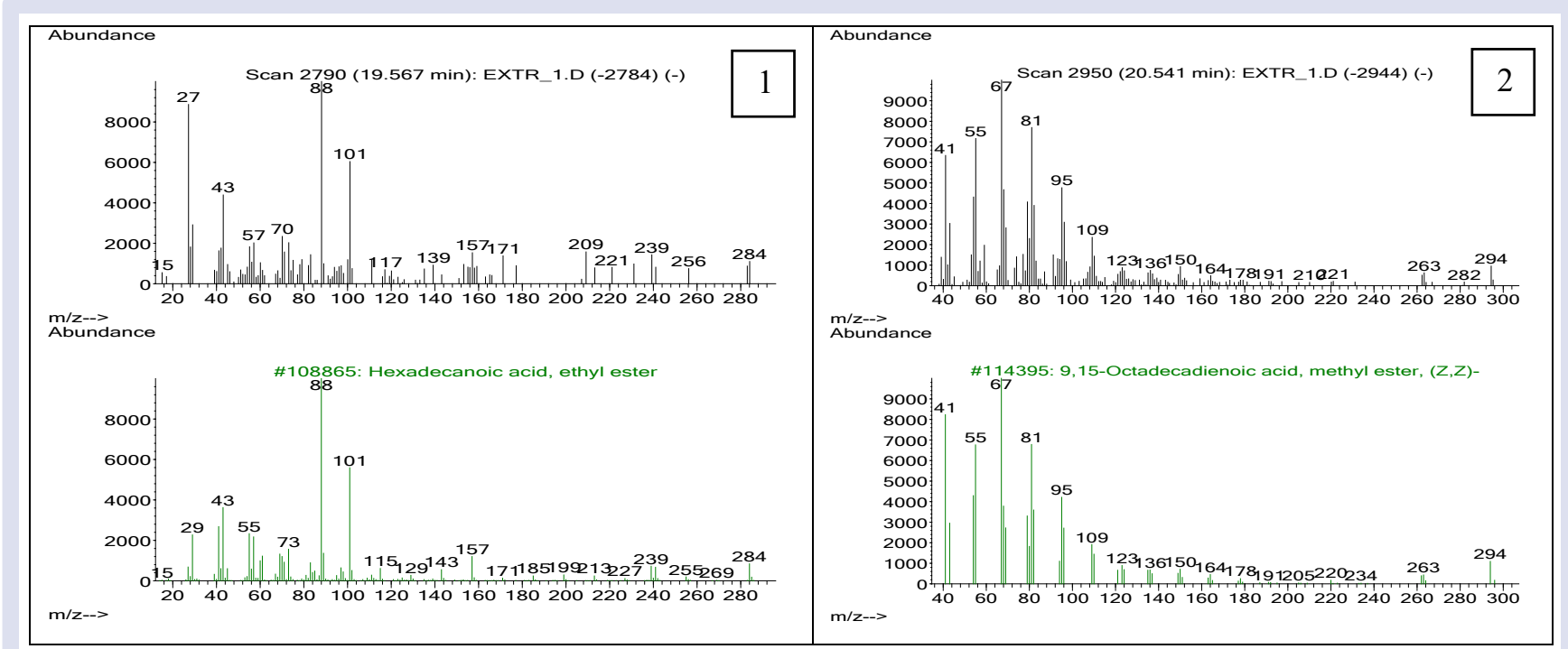

Figure 7: Hexadecanoic acid ethyl ester (1), [Z,Z]-9,15-Octadecadienoic acid methyl ester (2) mass-spectra.

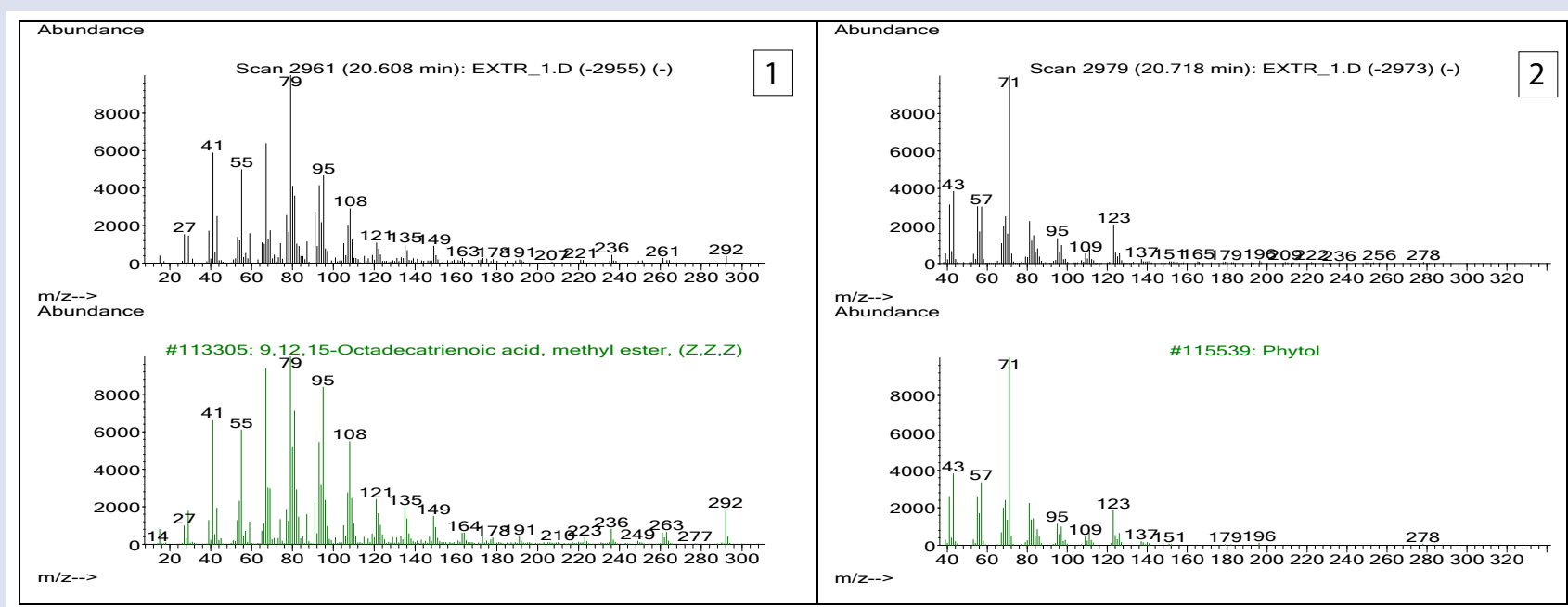

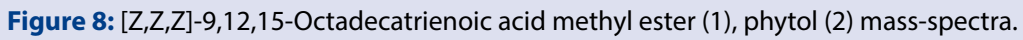

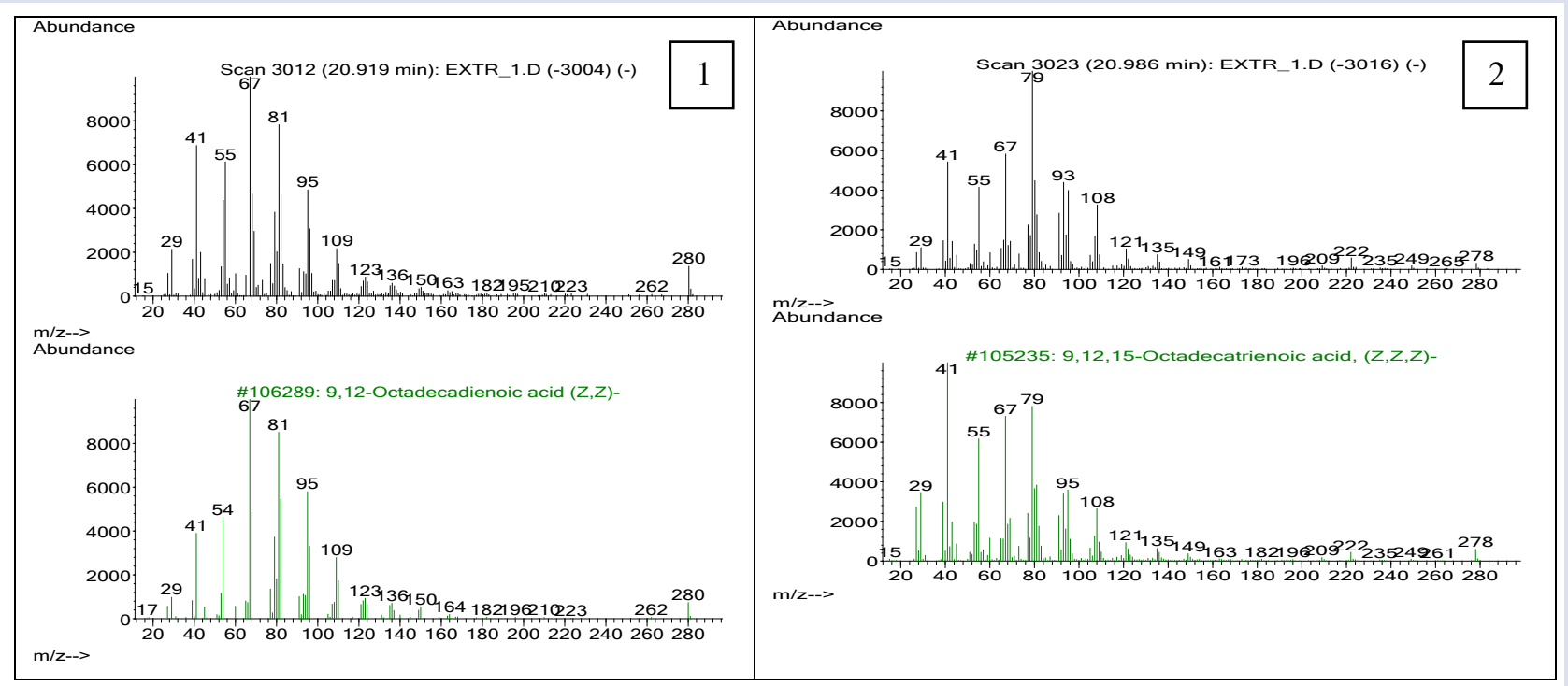

Figure 9: [Z,Z]-9,12-Octadecadienoic acid (1), [Z,Z,Z]-9,12,15-Octadecatrienolic acid (2) mass-spectra. 


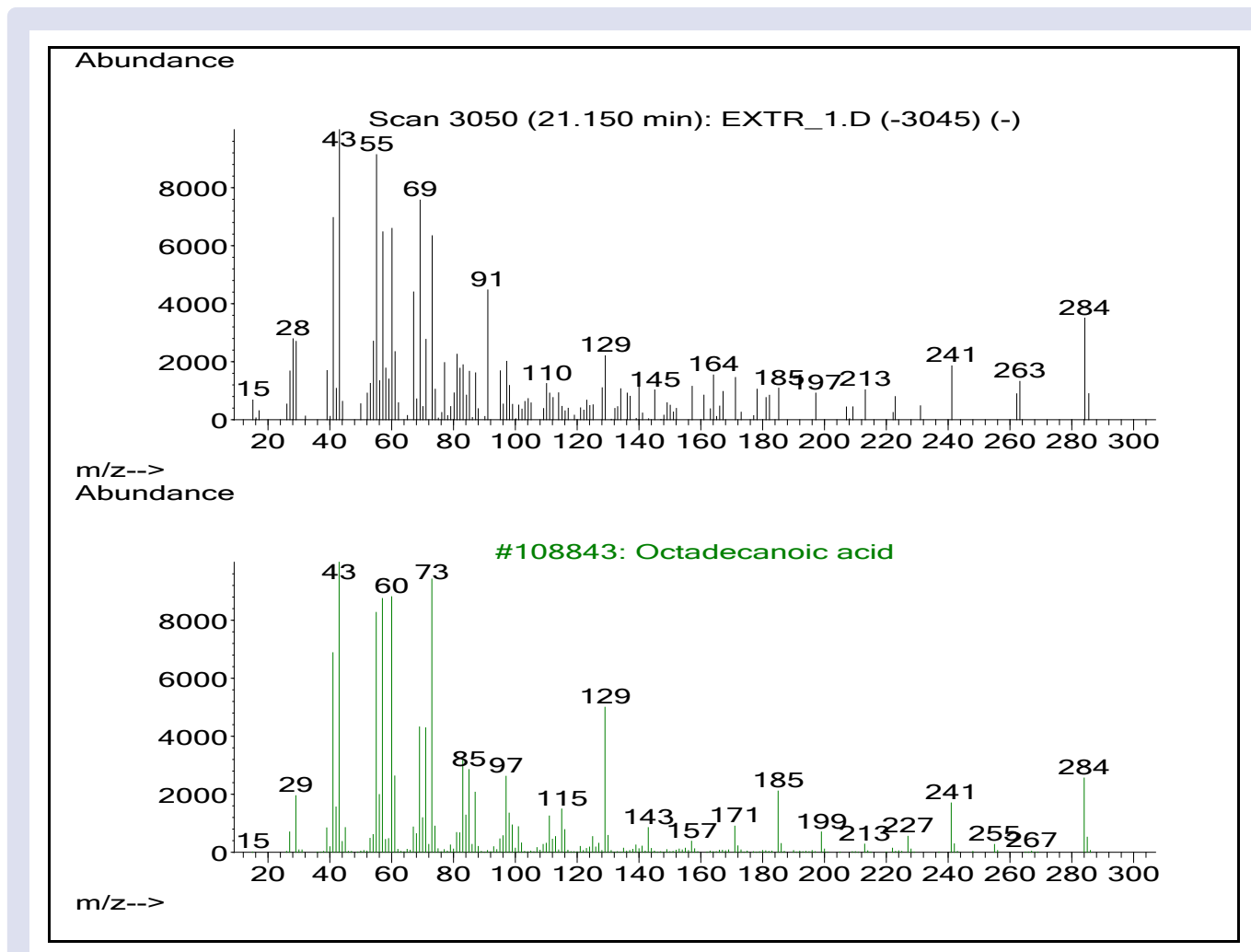

Figure 10: Octadecanoic acid mass-spectrum.

\section{ACKNOWLEDGEMENT}

This paper was financially supported by "Russian Academic Excellence Project 5-100".

\section{CONFLICTS OF INTEREST}

None.

\section{REFERENCES}

1. Plantarium. The determinant of plants on-line. Open Atlas of Plants and Lichens in Russia and Adjacent Countries. Galium verum L. (Rubiaceae fam.) [cited 2020 Feb 15]. Available from: https://www.plantarium.ru/page/image/id/597447.html

2. Mazko ON, Makarova OG, Kiryakova VO, Pashkov AP. Anti-inflammatory activity of Galium verum herb infusion. Bulletin of Med Sci. 2017;2:11-2.

3. Treben M. Health through God's pharmacy: Advice and experiences with medicinal herbs. Austria: Edition Ennsthaler Steyer. 118;2004.

4. Lakić N, Mimica-Dukić N, Isak J, Božin B. Antioxidant properties of Galium verum L. (Rubiaceae) extracts. Open Life Sciences. 2010;5(3):331-7.

5. Menshikova ZA, Menshikova IB, Popova VB. Medicinal plants in each house. Moscow: Vneshtorgizdat, p. 377;1991.

6. Bubenchikova VN, Ponaryina YuA. Achievements, problems and prospects of pharmaceutical science and practice. Proceedings of the Regional Scientific and Practical Conference dedicated to the 40th anniversary of the Faculty of Pharmacy of KSMU. edited by A.I. Lazarev. Kursk: KSMU, 2006;260-1.
7. Starchak YuA. The study of catchweed bedstraw herb triterpene compounds Proceedings of the II International Scientific Conference of Young Medical Scientists. Kursk: KSMU, 2008;304-5.

8. Il'ina TV, Kovaleva AM, Goryachaya OV, Aleksandrov AN. Essential oil from Galium verum flowers. Chemistry of natural compounds. 2009;45(4):587.

9. Bubenchikova VN, Yatsyuk VYa, Drozdova IL, et al. The study of the composition of organic acids of some representatives of the Central Chernozem flora. Proceedings of the XIV Russian National Congress "Human and Medicine"; 2007 Apr 16-20; Moscow, Russia. 2007.

10. Kondratova YuA, Katunina OS, Ponaryina YuA. The study of carotenoids of catchweed bedstraw herb. Proceedings of the 72 nd final, international conference of students and young scientists in 2 hours "Youth science and modernity"(Part II). Kursk: KSMU, 2007;129-30.

11. Ponaryina YuA. Development of a method for the quantitative determination of flavonoids in Lady's bedstraw herb. Proceedings of the 72nd final, international conference of students and young scientists in 2 hours "Youth science and modernity"(Part II). Kursk: KSMU, 2007;146-7.

12. Zhao CC, Shao JH, Li X, Kang XD, Zhang YW, Meng DL. Flavonoids from Galium verum L. Journal of Asian Natural Products Research. 2008;10(7):611-5.

13. Demi冈rezer LÖ, Gürbüz F, Güvenalp Z, Ströch K, Zeeck A. Iridoids, flavonoids and monoterpene glycosides from Galium verum subsp. verum. Turkish Journal of Chemistry. 2006;30(4):525-34.

14. Zhao CC, Shao JH, Li X, Xu J, Wang JH. A new anthraquinone from Galium verum L. Natural product research. 2006;20(11):981-4.

15. Kuznetsova MI, Kuznetsov SV, Zaichikova SG, Bondar AA. Investigation of the toxicity of yellow bedstraw (Galium verum) aqueous extract. Pharmacia. 2018;67(6):52-6. 


\section{GRAPHICAL ABSTRACT}

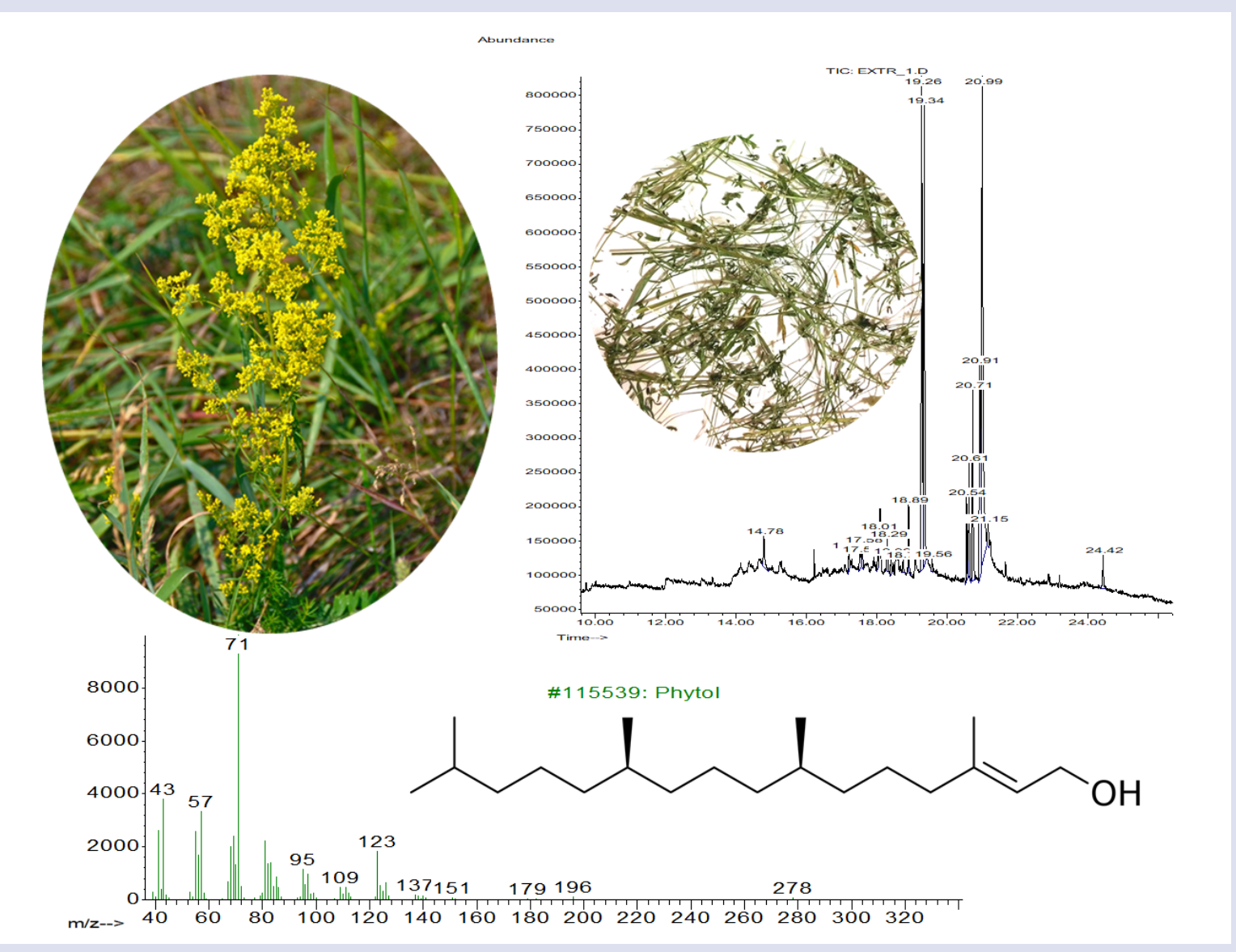

\section{ABOUT AUTHORS}

- Zaichikova Svetlana Gennad'evna: Doctor of Pharmaceutical Sciences (Dr.Sc.), Professor, Professor of Pharmaceutical Natural Sciences Department, A.P. Nelyubin Institute of Pharmacy, Sechenov University.

- Bokov Dmitry Olegovich: Candidate of Pharmaceutical Sciences (Ph.D.), A.P. Nelyubin Institute of Pharmacy, Sechenov University; Laboratory of Food Chemistry, Federal Research Center of Nutrition, Biotechnology and Food Safety.

- Kiselevskii Mikhail Valentinovich: Doctor of Medical Sciences (Dr.Sc.), Professor, Head of the Laboratory of Cell-Mediated Immunity, Blokhin National Medical Research Center of Oncology.

- Antsyshkina Alla Mikhailovna: Candidate of Pharmaceutical Sciences (Ph.D.), Associate Professor, Associate Professor of Pharmaceutical Natural Sciences Department, A.P. Nelyubin Institute of Pharmacy, Sechenov University.

- Bondar Alina Aleksandrovna: Candidate of Pharmaceutical Sciences (Ph.D.), Associate Professor of Pharmaceutical Natural Sciences Department, A.P. Nelyubin Institute of Pharmacy, Sechenov University.

- Prostodusheva Tatyana Vladimirovna: Candidate of Pharmaceutical Sciences (Ph.D.), Associate Professor, Associate Professor of Pharmaceutical Natural Sciences Department, A.P. Nelyubin Institute of Pharmacy, Sechenov University.

- Shchepochkina Olga Yurievna: Candidate of Pharmaceutical Sciences (Ph.D.), Associate Professor, Associate Professor of A.P. Arzamastsev Department of Pharmaceutical and Toxicological Chemistry, A.P. Nelyubin Institute of Pharmacy, Sechenov University.

- Gegechkori Vladimir Iraklievich: Candidate of Pharmaceutical Sciences (Ph.D.), Senior Lecturer of A.P. Arzamastsev Department of Pharmaceutical and Toxicological Chemistry, A.P. Nelyubin Institute of Pharmacy, Sechenov University.

Cite this article: Zaichikova SG, Bokov DO, Kiselevskii MV, Antsyshkina AM, Bondar AA, Prostodusheva TV, et al. Determination of the Chemical Composition of Lady's Bedstraw (Galium verum L.) Herb Extract by GC-MS. Pharmacogn J. 2020;12(4):857-63. 